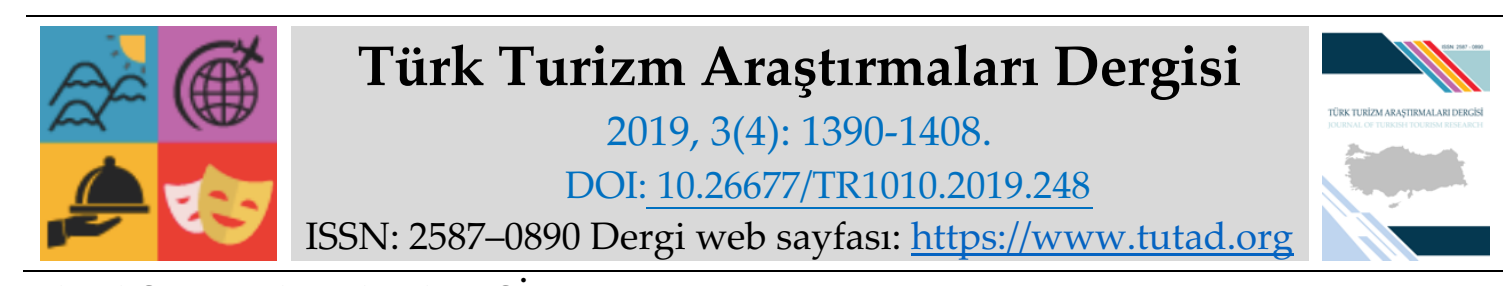

ARASTTIRMA MAKALESİ

\title{
AVM Ziyaret Sıklığının Yaşam Memnuniyeti, Yenilenme Deneyimi ve Deneyimleme Kalitesi Üzerindeki Etkisi: İstanbul’da Bir Araştırma
}

Öğr. Gör. Sercan YILDIZ, İstanbul Gelişim Üniversitesi, İstanbul Gelişim Meslek Yüksek Okulu, İstanbul, e-posta: seyildiz@gelisim.edu.tr ORCID: https://orcid.org/0000-0001-5246-6855

Öğr. Gör. Meltem ALTINAY ÖZDEMIR, Muğla Sıtkı Koçman Üniversitesi, Fethiye ASMK Yüksek Okulu, Muğla, e-posta: meltemozdemir@mu.edu.tr ORCID: https://orcid.org/0000-0002-3002-6127

Arş. Gör. Ayşegül ACAR, Karabük Üniversitesi, Safranbolu Turizm Fakültesi, Karabük, e-posta: aysegulacar@karabuk.edu.tr ORCID: https://orcid.org/0000-0002-1871-4904

Prof. Dr. Orhan AKOVA, İstanbul Üniversitesi, İktisat Fakültesi, İstanbul, e-posta: oakava@istabul.edu.tr

ORCID: https://orcid.org/0000-0001-7740-2938

Öz

$\mathrm{Bu}$ çalışmada bireylerin boş zamanlarında gerçekleştirdikleri alışveriş merkezi (AVM) ziyaretlerinin yaşam memnuniyeti, yenilenme deneyimleri ve deneyimleme kalitesi üzerindeki etkisinin araştırılması amaçlanmaktadır. Çalışma bireylerin boş zaman aktivitesi olarak AVM ziyaret sıklı̆̆ı ile yaşam memnuniyeti, yenilenme deneyimleri ve deneyimleme kalitesi arasındaki ilişkinin belirlenmesi açısından önemlidir. Alan araştırmasına yönelik yapılan bu çalışmada veriler, anket tekniği ile elde edilmiştir. Veriler kolayda örnekleme yöntemiyle İstanbul'daki alışveriş merkezlerini ziyaret eden bireylerden yüz yüze toplanmıştır. Verilerin analizinde faktör analizi, korelasyon analizi ve regresyon analizi kullanılmıştır. Analiz sonucunda; boş zaman aktivitesi olarak AVM ziyaret eden bireylerin yenilenme deneyimi ile deneyimleme kalitesi algıları arasında ve yine bireylerin yenilenme deneyimi, deneyimleme kalitesi ve AVM ziyaret sıklığı arasında pozitif yönlü bir ilişki olduğu saptanmıştır. Analiz sonucunda ayrıca boş zaman aktivitesi olarak AVM ziyaret eden bireylerin yaşam memnuniyeti algıları ile yenilenme deneyimi, deneyimleme kalitesi ve AVM ziyaret sıklı̆̆ı arasında anlamlı bir ilişki saptanamamıştır.

Anahtar Kelimeler: AVM Ziyaret Sıklığı, Yaşam Memnuniyeti Yenilenme Deneyimi, Deneyimleme Kalitesi

Makale Gönderme Tarihi: 17.06.2019

Makale Kabul Tarihi: 06.10.2019

Önerilen Atıf:

Yıldız, S., Altınay Özdemir, M., Acar, A. ve Akova, O. (2019). AVM Ziyaret Sıklığının Yaşam Memnuniyeti, Yenilenme Deneyimi ve Deneyimleme Kalitesi Üzerindeki Etkisi: İstanbul'da Bir Araştırma, Türk Turizm Araştırmaları Dergisi, 3(4): 1390-1408.

(C) 2019 Türk Turizm Araştırmaları Dergisi. 


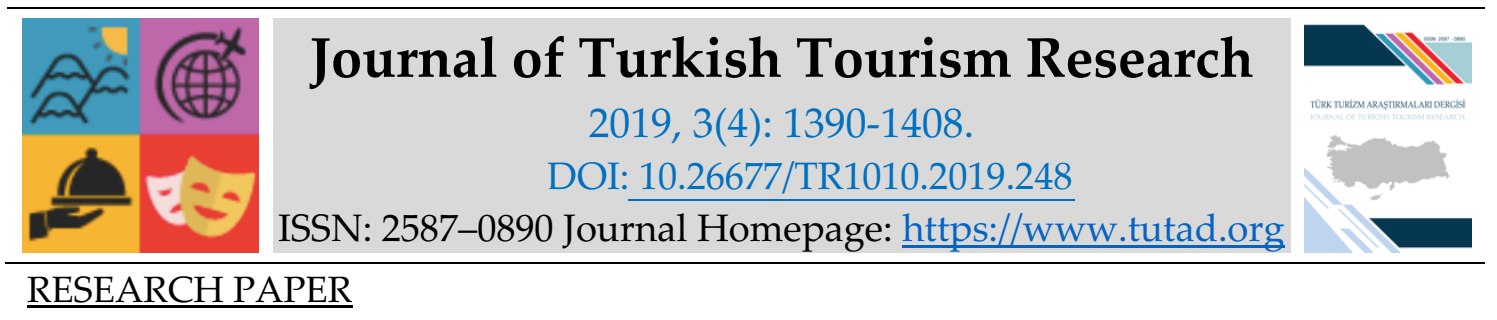

\title{
The Effect of Shopping Center Visiting Frequency on Life Satisfaction, Regeneration Experience and Experience Quality: A Research in Istanbul
}

Lecturer Sercan YILDIZ, İstanbul Gelişim University, İstanbul Gelişim Vocational High School, İstanbul, e-mail: seyildiz@gelisim.edu.tr ORCID: https://orcid.org/0000-0001-5246-6855

Lecturer Meltem ALTINAY ÖZDEMİR, Muğla Sıtkı Koçman University, Fethiye ASMK High School, Muğla, e-mail: meltemozdemir@mu.edu.tr ORCID: https://orcid.org/0000-0002-3002-6127

Research Assistant Ayşegül ACAR, Karabük University, Safranbolu Faculty of Tourism, Karabük, e-mail: aysegulacar@karabuk.edu.tr ORCID: https://orcid.org/0000-0002-1871-4904

Prof. Dr. Orhan AKOVA, İstanbul University, Faculty of Economics, İstanbul, e-mail: oakava@istabul.edu.tr

ORCID: https://orcid.org/0000-0001-7740-2938

\begin{abstract}
In this study, it is aimed to investigate the effect of visits of shopping center (AVM) that individuals perform in their spare time on life satisfaction, regeneration experience, experience quality. The study is important in terms of determining the relationship between the frequency of AVM visit as a leisure activity and the quality of life satisfaction, regeneration experiences and experience quality. Data were obtained by survey technique. The data were collected face to face from the individuals who visited the shopping centers in Istanbul by means of convenience sampling method. Factor analysis, correlation analysis and regression analysis were used to analyze the data. As a result of the analysis, it was determined that there was a statistically positive correlation between the regeneration experience and experience quality of individuals visiting AVM as leisure activity and also between experience quality and the frequency of visiting the AVM. Besides, as a result of the analysis, no significant relationship was found between the perceptions of life satisfaction of the individuals visiting AVM as a leisure activity and the regeneration experience, experience quality, and frequency of AVM visits.
\end{abstract}

Keywords: Indoor Recreation Activities, Life Satisfaction, Regeneration Experience, Experience Quality. Received: 17.06.2019

Accepted: 06.10.2019

Suggested Citation:

Yıldız, S., Altınay Özdemir, M., Acar, A. and Akova, O. (2019). The Effect of Shopping Center Visiting Frequency on Life Satisfaction, Regeneration Experience and Experience Quality: A Research in Istanbul, Journal of Turkish Tourism Research, 3(4): 1390-1408.

(C) 2019 Türk Turizm Araştırmaları Dergisi. 


\section{Gíriş}

Boş zaman, bireylerin gönüllü olarak kendi iradeleri doğrultusunda, fizyolojik ihtiyaçların karşılanmasından ve işten arda kalan zaman olarak tanımlanmaktadır (Clawson ve Kenetsch, 1971; Toker, Çankaya ve Doğan, 2003). Rekreasyon kavramı ise; yenilenme, yeniden yaratılma veya yeniden yapılanma anlamına gelen "recreatio" kelimesinden türemekte (Ozankaya, 1980) ve Türk Dil Kurumu'na göre 'İnsanların boş zamanlarında, eğlence ve spor amacı ile gönüllü olarak katıldıkları etkinlikler', 'Bir bölgeyi insanların eğlenme, dinlenme amacıyla kullanabilecekleri bir duruma getirme' anlamina gelmektedir (Türk Dil Kurumu, 2018). Alan yazında yapılan diğer tanımlara göre rekreasyon, kişiyi zorunlu iş ve etkinliklerinden sonra yenileyen, hayata bağlayan, dinlendiren, eğlendiren ve zevk verici eylemlere gönüllü olarak katılmak veya bu etkinliklere katılımla zihnen ve bedenen yenilenme olarak tanımlanmaktadır (Bucher ve Bucher, 1974; Edginton ve Ford, 1985; Kraus, 1985; Sağcan, 1986; Bayer, 1992; Karaküçük, 2001). Temel olarak gönüllülük esasına dayanan rekreasyon faaliyetleri, bireyi monotonluktan uzaklaştırarak faaliyet süresince özgürlük hissi ve haz vermenin yanı sıra bireysel ve toplumsal yararlar sağlamaktadır (Eren, 2009). Rekreasyon faaliyetlerinin kapsam olarak geniş olması her zaman ve her yerde yapılabilecek bir aktivitenin olması bireylere nerede olurlarsa olsunlar hem zihinsel hem de fiziksel açıdan rahatlama olanağı sunmaktadır. Fakat rekreasyonun kapsam olarak geniş olması özelliklerine göre sınıflandırılmasını gerekli kılmaktadır. Literatürde en yaygın görünen sınıflandırmanın ilki toplumsal, kültürel, sanatsal, sportif, turizm ve dinlenme amaçlarını kapsayan amaçlara göre yapılan sınıflandırmadır. Diğer bir sınıflandırma ise, aktif ve pasif katılımı destekleyen eylem çeşidine ve açık-kapalı olarak mekâna göre yapılan sınıflandırmadır (Karaküçük, 2001; Mirzeoğlu, 2003). Bu çalışmanın ana temasını oluşturan alışveriş merkezleri ise, bu sınıflandırmada mekânsal olarak kapalı alan rekreasyonu kapsamında değerlendirilmektedir.

Küreselleşme süreci ve değişen tüketici ihtiyaçları, bireylerin kısıtlı boş zamanlarında yöneldikleri rekreasyonel aktivitelerinin niteliğini etkilemektedir. Öyle ki, günümüzde bireyler, kısıtlı zamanlarını iyi yönetmek ve zamandan tasarruf etmek için gerek günlük ihtiyaçlarını (kıyafet, market alışverişi vb.), gerekse sosyal ve psikolojik ihtiyaçlarını giderebilmek amacıyla, her şeyin bir arada yer aldığı mekânları tercih etmeye başlamışlardır. Bu sayede, alışveriş merkezleri bireylerin "bedenlerini ve zihinlerini dinlendirme, yenilenme ihtiyacı" olarak tanımlanan rekreasyonel aktivitelerini gerçekleştirebileceği mekânlar haline gelmiştir. Alışveriş merkezlerinden rekreatif bir faaliyet olarak ilk kez Bellenger ve Korgaonkar (1980)'ın yapmış oldukları çalışmalarında bahsedilmiştir. Bireyler, herhangi bir şey satın almasalar bile alışveriş deneyiminin kendisinin bir rekreatif faaliyet olarak kabul edilmesi gerektiğini ifade etmişlerdir (Eastlick, Lotz ve Shim, 1998). Böylece, günümüzde eğlence ve alışveriş kavramları bir araya gelmiş ve retailing ile entertainment kelimeleri birleştirilerek eğlenceli alışveriş kavramı ve alışverişçiyi eğlendirme gibi kavramlar ortaya çıkmıştır (Argan, 2007). Kavramal değişimlerin etkisiyle, artık insanların ihtiyacı dâhilinden ziyade rekreasyonel ve hedonik açıdan alışveriş merkezlerini ziyaret ettikleri görülmektedir (Altınay ve Bilgimöz, 2015). Günden güne eklenen rekreatif fonksiyonlarıyla bireylerin boş zamanları için adeta bir "cazibe merkezi" haline gelen bu yapılar, bireylerin yenilenme deneyimini ve deneyimleme kalitesini büyük ölçüde etkilemesi ve beraberinde yaşamlarından duyduğu memnuniyetlerini de artırması açısından modern insan hayatında önemli bir yer tutmaya başlamıştır. Bu yüzden AVM'lerin boş zaman faaliyetleri açısından yenilenme deneyimi sunması ve bu deneyimin, deneyim kalitesi ve yaşam memnuniyeti üzerindeki etkisinin araştırılması gerekliliği ortaya çıkmıştır. Bu nedenle, çalışmada bir boş zaman faaliyeti olarak AVM ziyaretlerinden edinilen yenilenme deneyimi ile deneyimleme kalitesi ve yaşam memnuniyeti arasındaki ilişkinin tespit edilmesi 
amaçlanmaktadır.

\section{LITERATÜR TARAMASI}

\section{Kapalı Alan Rekreasyon Aktivitesi Olarak AVM Ziyareti}

Kapalı alan rekreasyonu; bireylerin boş zamanlarını etkin bir şekilde kullanmak ve çağdaş toplumda hayat kalitesini artırmak amacıyla, kapalı alanlar dâhilinde yaptıkları rekreasyonel faaliyetlerin tümü olarak tanımlanmaktadır. Bu rekreasyon türü, bireylerin iş zamanı haricinde özel ve kamu kurumlarında ya da özel alanlarda yaptıkları faaliyetleri kapsamaktadır. Bir başka deyişle kapalı alan rekreasyonu, insan eliyle yapılan mekânların ergonomik kullanımına imkân veren her türlü yararlı faaliyeti ihtiva eden bir unsur olarak nitelendirilebilir (Kılıç ve Şener, 2013). Özetle, bu rekreasyon türü, konutlar başta olmak üzere, geliştirilen türlü iç mekanlarda sürdürülen rekreasyon türlerinden biri olup, özellikle bireylerin günlük hayatlarındaki yeri ve yaygınlığıyla bilinmektedir (Müderrisoğlu ve Uzun, 2004). Bireyler iş dışındaki (hafta içi mesai çıkışı ve hafta sonu) vakitlerini en verimli şekilde değerlendirmek istemekte, bunun için de gezmek, dolaşmak, alışveriş yapmak ve eğlenmek gibi sosyal aktivitelerini bu zaman dilimlerine sığdırmaya çabalamaktadırlar. Bu tanıma en uygun mekânların başında ise şüphesiz AVM'ler gelmektedir (Şentürk, 2012). Geçmişte, alışveriş merkezleri, temel birtakım ihtiyaçların giderilmesinden ibaret olan alışveriş eylemi, artık pek çok insan için alışverişten haz duyulmasına gerek olan eğlence bazlı alışverişe, farklı bir deyişle rekreatif alışverişe dönüşmüştür. Bu açıdan bakıldığında rekreatif alışveriş, bireylerin boş zamanlarında gerçekleştirdikleri alışveriş aktivitelerini, içsel tatmin duymak, haz almak ve eğlenceli anlar deneyimlemek amacıyla geçirmesi bakımından genel alışveriş, kavramından uzaklaşan, farklı bir alışveriş tarzı olarak karşımıza çıkmaktadır (Kaya, 2014). Literatürde yeni yeni üzerinde durulmaya başlanan bu kavram, Kaya (2014) tarafından yapılan bir çalışmada ölçek haline getirilmiştir. Söz konusu "Alışveriş Merkezi Tüketicilerine Yönelik Rekreatif Alışveriş Ölçeğinin alt boyutları ise; "duygusal deneyimler", "hedonik alışveriş", "keşfetme/macera alışverişi", "sosyal amaçlı alışveriş̧" ve "fırsat alışverişi" olarak belirlenmiştir. İstanbul il sınırları içerisindeki alışveriş merkezleri üzerinde yapılan çalışmadan elde edilen bulgular ışığında, rekreatif alışverişi en iyi temsil eden iki boyutun "duygusal deneyimler" ve "hedonik alışveriş" olduğu tespit edilmiştir.

Son yıllarda neredeyse adım başı rastlanılan yapı türlerinden biri olan alışveriş merkezleri, yaşanan toplumsal ve ekonomik değişim sürecinin somut bir ürünü olarak ortaya çıkmaktadır. Değişen hayat tarzları, hayatımızın merkezinde yer alan yeni iktisadi sistemler, henüz ortaya çıkan toplumsal gereksinimler neticesinde alışveriş, merkezleri toplumun büyük bir çoğunluğu için yeni rekreasyon merkezlerine dönüşmüştür. Yaşanan bu toplumsal dönüşüm, rekreasyon kavramında ve rekreasyon mekanlarında da önemli değişiklikler yaşanmasına neden olmuştur. Temelinde bireylerin kendini yenilemesine ve kişisel gelişimine hizmet etmeyi amaç edinen bir kavram olarak tanımlanan rekreasyon kavramı; bu bireysel ve toplumsal niteliklerini, kapitalist sistemin tüketimi dayatması neticesinde yavaş yavaş yeniden şekillendirmeye başlamıştır. Modern dünyada bireyler, tüketim bazlı faaliyetler içerisinde rekreasyon gereksinimini karşılamaya doğru yöneltilmişlerdir. Alışveriş merkezleri, bu toplumsal olgunun, mekânsal tasviri olarak hayatımıza dâhil olmuştur (Aktaş, 2011).

Günümüzün modern alışveriş merkezleri, çoğu ziyaretçi için yeni rekreasyon alanları olarak hizmet vermeye başlamış ve toplumun en önemli rekreasyonel tüketim merkezleri haline gelmişlerdir. Öyle ki, her şeyin tüketildiği mekanlar olarak tasvir edilen bu yeni rekreasyon alanlarında, rekreasyon kavramı da tüketilen bir ürün olarak nitelendirilmektedir (Aktas, 2011). 
Alışveriş merkezlerinin, modern şehir hayatı için ticari bir merkez olmanın da ötesinde sosyal ve kültürel bir merkez olarak bireylere hizmet etmesi gerektiğini vurgulayan Victor Gruen'e karşın günümüzün modern alışıveriş merkezleri, gelişen ve artan üretim/tüketim sistemlerinin devir hızının yükseltilebilmesi ve devamlılı̆̆ın tesis edilebilmesi için birer öncü güç olarak hizmet vermektedirler. Bu nedenledir ki, bireylerin kapalı alan rekreasyon faaliyetleri arasında yer alan alışveriş merkezleri, tüketimin devir hızının moda, gelip geçicilik vb. unsurlar ile yükseldiği ve tüketimin devamlılığının sağlandığı birer ticari merkez haline dönüştürülmüşlerdir. Söz konusu bu merkezler, gündelik yaşamın her anı organize edilmiş olan şehir insanlarının, şehir hayatı içinde ancak şehrin dışında bir araya gelebildikleri ortak alanlar olarak nitelendirilmektedir (Sayar ve Süer, 2005).

1980'li yıllarda ülkemizde etkisini göstermeye başlayan liberalleşme süreci ve farklılaşan küresel etkenler, alışveriş merkezlerinin de şehir kimliğinin bir parçası haline dönüşmesinde bir etken olmuştur. 1990'lı ve 2000'li yıllarda alışveriş merkezleri dünyanın pek çok şehrinde hızla yaygınlaşmış ve bu durum beraberinde şehir merkezlerinin gittikçe daha az tercih edilir hale gelmesine sebebiyet vermiştir. Her ne kadar alışveriş merkezlerinin ülkemizdeki yaygınlaşma süreci yeni olsa da tüketim kültürünün eğlence ve alışveriş anlayışını teşvik etmesiyle birlikte, insanların alışveriş merkezlerine uyumu da oldukça basit bir şekilde gerçekleşmiştir (Erkip, 2003). Nitekim alışveriş merkezleri, tüketime yönelik mal ve hizmetlere ilişkin pek çok ulusal ve uluslararası markayı bünyesinde barındırmasının yanı sıra, çocuklu aileler için alışveriş sırasında çocuklarını emanet edebilecekleri çocuk bakım mağazaları, oyun alanları, çiçekçi, kuru temizleme, sinema, oto yıkama hizmeti, kuaför, bowling salonu, buz pisti vb. birçok aktivite imkânı sunması açısından da bireylerin hayatlarını bir nebze kolaylaştırmakta, sosyal ihtiyaçlarını da karşılamasını sağlamaktadır. Bu açıdan düşünüldügünde alışveriş merkezleri, özellikle trafiğin yoğun olduğu büyük illerde ve kalabalık metropollerde yaşayan bireyleri, iş yaşamının stresinden, çağdaş şehir yaşamının tekdüzeliğinden, gündelik işlerin karmaşıklığından sıyırarak; onların boş zamanlarını keyifli ve verimli bir şekilde geçirmelerine olanak sağlamaktadır (Şentürk, 2012).

Alı̧̧veriş aktivitesi bireyler tarafından kapalı alanlarda gerçekleştirilen rekreasyonel bir aktivite olarak değerlendirildiğinde, mal/ hizmet gereksinimini gidermenin yanı sıra, alışveriş yapan bireylerin sosyalleşme gereksinimlerinin giderilmesini de kapsadığı görülmektedir. Bu durum, alışveriş faaliyetini bünyesinde ihtiva eden yapıların da türlü eklentilerle geliştirilmesine ve zenginleştirilmesine vesile olmuştur (Sayar ve Süer, 2005). Çalışmasında günümüz alışveriş, merkezlerindeki yaşam pratiğini değerlendiren Baudrillard (1997) ise, alışveriş merkezlerinin tüm aile bireylerine yönelik faaliyetler ile kendilerini herkesçe yeğlenebilir mekânlar haline dönüştürmeye çabaladıklarını dile getirmiştir. Baudrillard'a (1997) göre, alışveriş merkezleri kullanıcılarına tüm olanakları bünyesinde barındıran küçük bir şehir yaşamı simülasyonu sunma eğilimindedir. Bunu tesis etmek için ise, alışveriş merkezi tasarımında şehri andıran pek çok unsurun iç mekânda yinelendiği gözlenmektedir. Bu çabalara örnek olarak; koridorlar boyunca yürünen, adeta şehirlerin sokaklarını anımsatan, etrafı dükkânlarla çevrili alışveriş, aksları, bireyleri çoğunlukla şehirlerdeki emsallerini anımsatan alışveriş, merkezindeki faaliyetin odak noktası olan meydanlar verilebilir (Aktaş, 2011).

Kapalı rekreasyon alanları olarak hizmet veren ve en büyük gayesi kapalı bir "kentsel mekân" yaratabilmek olan alışveriş merkezlerine rağbet eden bireylerin, bu talebinin altında yatan temel neden, bireylerin sosyal ihtiyaçlarını karşılayabilme ve psikolojik olarak rahatlayabilme arzusu duymalarıdır (Bozkurt ve Ulus, 2014). Bu bilgiler doğrultusunda araştırmanın hipotezi aşağıdaki gibidir. 


\section{H1: AVM ziyaret sıklı̆̆ yaşam memnuniyetini arasında istatistiksel olarak anlamlı bir ilişki vardır.}

Günümüzde alışveriş merkezleri bireylerin gereksinimlerini tam anlamıyla karşılayabilmek, müşterilerine her geçen gün daha farklı deneyimler yaşatabilmek ve müşterilerinin yenilenme deneyimleri ile deneyimleme kalitelerini yükseltmek için yoğun bir çaba göstermektedirler. Türkiye'de son dönemde açılan İstanbul Forum Alışveriş Merkezi'ndeki buz müzesi ve SeaLife akvaryum, Torium alışveriş merkezindeki kayak pisti ve snowpark alanı, Aplus alışveriş merkezindeki çocuklara yönelik tasarlanmış golf sahaları, Ankara Panora ve Optimum alışveriş merkezlerindeki buz pateni sahaları bu çabalara örnek olarak gösterilebilir. Bu örneklere ilişkin araştırmanın hipotezi aşağıdaki gibidir.

\section{H2: AVM ziyaret sıklığı yenilenme deneyimini olumlu yönde etkilemektedir.}

AVM ziyaretlerinin sadece yaşam memnuniyeti ve yenilenme deneyiminin yanı sıra deneyimleme kalitesi üzerinde de etkili olabileceği düşünülmektedir. AVM'lerde deneyimleme imkânı sunan aktivitelerin çeşitlilik göstermesi bireylerin deneyimleme kalitesi algısını daha da arttırmaktadır. Bunun yanı sıra bireylerin boş zamanlarında rahatlamak amacıyla gittikleri AVM'lerde hizmet sunan işletmelerle ve bireylerle etkileşimleri deneyimleme kalitesini pozitif ya da negatif yönlü etkilemektedir. Genellikle AVM'lere yönelik pozitif yönlü duyuşsal tutumun oluşması AVM' lerin tekrar edilme oranlarını arttırmaktadır. AVM'lerin tekrar tekrar ziyaretleri ise bireylerin deneyimleme kalitesi üzerinde etkili olabilmektedir. Bu yüzden bu görüşe ilişkin araştırmanın hipotezi aşağıdaki gibidir.

H3: AVM ziyaret sıklı̆̆l deneyimleme kalitesini olumlu yönde etkilemektedir.

\section{Boş Zaman Faaliyetlerinde Yenilenme Deneyimi, Deneyimleme Kalitesi ve Yaşam Memnuniyeti}

"Yenilenme" kavramı; bireylerin yaşadıkları zorlukların bir sonucu olan yıpranmış ruh hallerinin iyileşmesiyle ortaya çıkan bir olgudur. Daha açık bir ifadeyle yenilenme; stres unsurlarının yok olması ile meydana gelen ve bireyin çalışma dışındaki akşam saatlerinde veya hafta sonlarında mikro seviyede, uzun süren tatil zamanlarında (örneğin yıllık izinlerinde) ise, makro seviyede gerçekleşen bir iyi olma halidir (Sonnentag ve Fritz, 2007; Derks ve Bakker, 2014; Chen vd., 2014; Altunel ve Akova, 2016). Chen ve diğerleri (2016)'ne göre yenilenme, mikro ve makro düzeyde olmak üzere iki şekilde gerçekleşmektedir. Buna göre, kısa süren iş dışı zamanlar (akşam saatleri ve hafta sonları gibi) mikro düzeyi, insanların iş dışı zamanda ve uzun süre boyunca rahatsız edilmeden tamamen yenilenme için uzun süreli tatillere çıkması makro düzeyi açıklamaktadır (Altunel ve Akova, 2016). Bu nedenle bireylerin mikro düzeyde rekreasyonel olarak gittikleri AVM ziyaretlerinden edindikleri yenilenme deneyimin deneyimleme kalitesini pozitif yönde etkilediği düşünülmektedir. Buna göre araştırmanın hipotezi aşağıdaki gibidir.

\section{H4: Yenilenme deneyimi, deneyimleme kalitesini olumlu yönde etkilemektedir.}

Deneyim, bir ürünün veya hizmetin edinilmesi, kullanılması hakkında öğrenme süreci sırasında kazanılan izlenimidir (Carbone ve Haeckel, 1994; Berry vd., 2002). Deneyimler esas olarak kişisel yaşantılara dayanmaktadır (Pine ve Gilmore, 1998). Deneyim kalitesi ise hizmet kalitesi ile ilişkili olarak literatüre kazandırılan bir kavramdır (Csikszentmihalyi ve LeFevre, 1989; Fick ve Ritchie, 1991; Chang ve Horng, 2010). Csikszentmihalyi ve LeFevre (1989) 
deneyimleme kalitesini açıklarken bireylerin deneyimlerini kişisel olarak nasıl değerlendirdiğine ve nasıl hissettiğine odaklanmıştır (Csikszentmihalyi ve LeFevre, 1989). Chang ve Horng (2010) da buna paralel olarak deneyimleme kalitesinin, tüketim faaliyetlerine katılan bireylerin hizmet çevresi, hizmet sağlayıcıları, diğer tüketiciler ve unsurlarla etkileşim halindeyken yaşadıkları deneyimi duygusal açıdan nasıl değerlendirdiklerini ifade ettiğini söylemektedir (Chang ve Horng, 2010). Deneyimleme kalitesinin en önemli özelliği hizmetlerin tüketimi aşamasında etkileşimler aracılığıyla elde edinilmesidir. Bu açıdan, bireylerin rekreatif olarak AVM ziyaretlerindeki deneyimleme kalitesi yaşam memnuniyetini pozitif olarak etkilediği düşünülmektedir. Buna yönelik araştırmanın hipotezi aşağıdaki gibidir.

\section{H5: Deneyimleme kalitesi, yaşam memnuniyeti arasında istatistiksel olarak anlamlı bir ilişki vardır.}

Basit bir tanımla sadeleştirilemeyecek kadar çok faktörü bünyesinde barındıran "yaşam memnuniyeti" kavramı bireyin iş, boş zaman ve diğer çalışma dışı zaman olarak tanımlanan hayata yönelik gösterdiği duygusal tepkiler veya tutumlar olarak tanımlanmaktadır (Dikmen, 1195). Yaşam memnuniyeti, kapsamlı bir mutluluğun önemli bir öğesi olmakla birlikte bireylerin kendi yaşam örüntüleri ve standartları ile ilişkili süreçlerin bir bütünüdür (Kanbur ve Özdemir, 2017). Bireylerin yaşam memnuniyeti birçok unsura bağlı olarak değişkenlik göstermektedir (Wagner, 2006; Maddison ve Rehdanz, 2011; Akgündüz, 2013; Ngoo, Tey ve Tan, 2015; Proto ve Rustichini, 2015). Bu unsurlar temel olarak; “araçsal rahatlık, sağlık ve kişisel güven, anne/baba/kardeşler ve diğer akrabalarla ilişkiler, bir çocuğa sahip olma ve onu büyütme, karı-koca ilişkisinde yakınlık, yakın arkadaşlara sahip olma, başkalarına yardım etme ve başkalarını gözetme, devletin yerel ve ulusal etkinlikleriyle, halk etkinliklerine katılma, öğreniyor olma, kendini anlayabilme, bir işte çalışıyor olma, kendini tanımlayabilme, toplumsallaşma, kitap okuma, müzik dinleme, sinema veya maç vb. seyretme ile eğlenceli etkinliklere katılma" dır (Dikmen, 1995). Literatürde boş zamanın yaşam memnuniyetine olan etkisini vurgulayan birçok çalışma (London, vd., 1977; Coyle, vd., 1994; Neal vd., 1999; Gilbert ve Abdullah, 2004; Neal vd., 2007; Sirgy vd., 2011; Agyar, 2013; Lapa, 2013; Lin vd., 2013; Lepp, 2018; Uysal ve Sirgy, 2019). bulunmakla birlikte bu çalışmada rekreatif aktivite olarak AVM ziyaretlerinden edinilen yenilenme deneyiminin yaşam memnuniyetini pozitif yönde etkilediği düşünülmektedir. Bu bilgiler ışı̆̆ında araştırma hipotezi aşağıdaki gibidir.

H6: Yenilenme deneyimi yaşam memnuniyeti arasında istatiksel olarak anlamlı bir ilişki vardır.

Son 60 yıl içinde hızlı bir gelişme gösteren İstanbul'da nüfus artışı ile konut sayısında kayda değer artışlar yaşanmış ve buna paralel olarak kent için yeşil alanların sayısında azalmalar olmuştur (Türkoğlu, Bölen, Korca ve Marans, 2008). Kent yaşamında konut, ulaşım, kamu hizmetleri, iş olanakları ve çevre kalitesinde görülen eşitsizliklere ek olarak şehrin rekreasyonel olanakları da İstanbul'da yaşayanların yaşam memnuniyetini etkilemektedir. İstanbul'un metropolitan bir şehir olması ve kent için yeşil alanların az olması ya da açı alanlarda yapılabilecek aktivitelerin İstanbul'da yaşayanların sayısına kıyasla yetersiz kalması, insanları kapalı rekreasyon aktivitelere yöneltmiştir. Kapalı rekreasyon alanlarından en yaygın olanı ise hem yetişkinler hem de çocuklar için çeşitli olanakları içinde barındıran AVM'dir. Özellikle İstanbul'daki AVM'lerin sayıca çok olması, çeşitli aktiviteler sunması ve hatta dönemsel olarak eğlenceli etkinliklere de ev sahipliği yapması insanlara mikro düzeyde (kısa süreli) boş zamanlarını değerlendirerek yenilenme imkânı sunmaktadır.

Bireylerin hayatlarından memnun olabilmeleri, sadece günlük ekonomik ihtiyaçların giderilmesinin yanında bireylerin gerek sosyal gerekse psikolojik ihtiyaçlarının karşılanmasını 
da gerektirir. Bu nedenle, bireylerin boş zamanlarında tercih ettikleri kapalı alan rekreasyonel aktivitelerden biri olan alışveriş merkezlerinin sunduğu deneyimlerin bireyler üzerinde yarattığı yenilenme deneyimi, bu deneyimin kalitesi ve bu aktivitelere katılmanın bireylerin yaşam memnuniyetleri üzerinde etkisinin değerlendirilmesi bu açıdan büyük önem taşımaktadır.

\section{YÖNTEM}

Bu çalışmada, bireylerin AVM ziyaret sıklıklarının yaşam memnuniyeti, yenilenme deneyimi ve deneyimleme kalitesi üzerindeki etkisinin incelenmesi amaçlanmaktadır. Çalışmada, nicel yöntemden yararlanılmış ve veriler, anket tekniği ile toplanmıştır. Anket formundaki ifadeler, çalışmanın amacına uygun bir şekilde belirlenmeye çalışılmış ve ifadelerin kısa ve anlaşılır olmasına özen gösterilmiştir. Verilerin elde edilmesinde kolayda örnekleme yöntemi kullanılmıştır. Bu örnekleme yöntemine ilişkin en önemli varsayım, evreni oluşturan her bir elemanın benzeşik (homojen) olması gerekliliğidir (İsmailoğlu, 2003). Dolayısıyla çalışmaya, boş zamanlarında AVM ziyaret etme deneyimi bulunulan (benzeşik) ve İstanbul'un önemli AVM'lerinin yer aldığı Beşiktaş, Taksim, Osmanbey, Beylikdüzü, Zeytinburnu, Kadıköy, Bakırköy semtlerinde yaşayan bireylerden toplanan 352 anket verisi dahil edilmiştir.

Araştırmada kullanılan anketin ilk bölümünde, katılımcılara yönelik demografik ve sosyoekonomik sorulara yer verilmiştir. İkinci bölümünde ise, katılımcıların boş zamanlarında AVM ziyaretlerine ilişkin yenilenme deneyimi, deneyimleme kalitesi ve yaşam memnuniyeti algılarının belirlenmesi amacıyla 29 adet ifadeye yer verilmiştir. Bu bölümde kullanılan ve katılımcıların yenilenme deneyimi algılarını ölçen ifadeler, temelini Sonnentag ve Fritz' in (2007) atmış olduğu Yenilenme Deneyimi Ölçeği'nden (REQ), katılımcıların deneyimleme kalitesine yönelik algılarını ölçen ifadeler, uluslararası ve ulusal alanyazında bir çok çalışmada kullanılmış, temeli Kang ve Gretzel (2012) tarafından atılmış olan Deneyimleme Kalitesi Ölçeği'nden (EXQ Scale) ve son olarak katılımcıların yaşam memnuniyeti algıları ölçen ifadeler ise, temeli Lavallee vd. (2007) tarafından atılmış Yaşam Memnuniyeti Ölçeği'nden (CLAS) uyarlanmış ve derlenmiştir. Kullanılan tüm ölçüm araçları, uluslararası ve ulusal alanyazında sıklıkla tercih edilmiş, geçerlilik ve güvenilirliği kanıtlanmıştır. Soruların anlaşılırlığı, açıklığı, kelime ve cümle yapıları kontrol edildikten sonra, konuyla ilgili uzmanlardan alınan görüşler neticesinde anket ifadelerinde gerekli düzenlemeler yapılarak, ankete son şekil verilmiştir. Katılımcıların algıları, yedi maddeli Likert tipi dereceleme ile ölçülmüştür.

\section{Araştırmanın Kavramsal Modeli}

$\mathrm{Bu}$ araştırma, AVM ziyaret sıklığının yaşam memnuniyeti, yenilenme deneyimi ve deneyimleme kalitesi üzerindeki etkisini ortaya koymayı amaçlamaktadır. Araştırma sürecinde yenilenme deneyiminin deneyimleme kalitesi ve yaşam memnuniyeti ile ilişkisi ve deneyimleme kalitesinin yaşam memnuniyeti ile ilişkisi araştırmanın alt amaçlarını oluşturmaktadır. Bu doğrultuda araştırmanın kavramsal modeli aşağıdaki gibidir. 


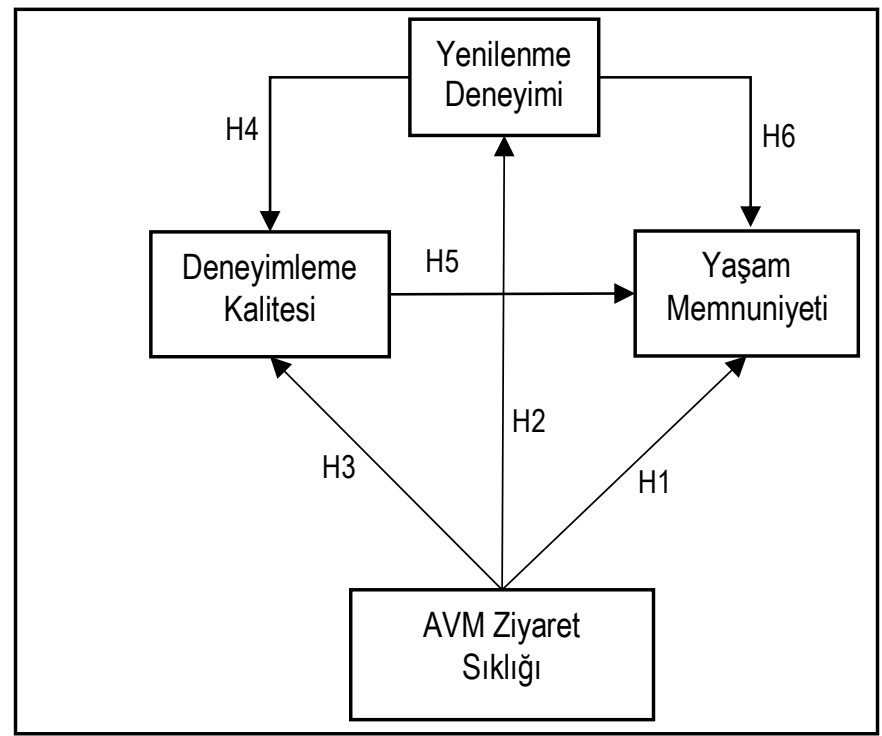

Şekil 1. Araştırmanın Kavramsal Modeli

\section{Ölçeklere İlişkin Güvenilirlik ve Geçerlilik Analizleri}

Alan yazında, ölçek güvenilirliğiyle ilgili en sık kullanılan yöntem, iç tutarlılık (alpha katsayısı) analizi yöntemidir. Ölçeklere ilişkin gerçekleştirilen güvenilirlik analizleri sonucunda, çalışmada kullanılan yenilenme deneyimi ölçeğinin iç tutarlılık değeri 0,848 olarak, deneyimleme kalitesi ölçeğinin iç tutarlılık değeri 0,893 olarak ve son olarak yaşam memnuniyeti ölçeğinin iç tutarlılık değeri ise 0,668 olarak ölçülmüştür. Yaşam memnuniyeti ölçeği iç tutarlılık değerinin görece düşük çıkması, ilgili ölçeğin minimum ifade sayısı ile ölçülmeye çalışılmasından kaynaklandığı söylenebilir (Chakrapani, 2004). Bulunun tüm iç tutarlılık değerleri, araştırmada kullanılan ölçeklerin güvenilir olduğunun göstergesidir (Cronbach, 1990).

Araştırmada kullanılan ölçeklerin geçerliliklerinin test edilmesi amacıyla ise açıklayıcı faktör analizi yöntemi kullanılmıştır. Bir ölçeğe ait geçerliliğin açıklayıcı faktör analizi ile belirlenmesi için, öncelikle o ölçüme ait verilerin uygun olması gerekmektedir. Verilerin açıklayıcı faktör analizine uygunluğu, KMO (Kaiser-Meyer-Olkin) katsayısı ve Barlett Küresellik Testi ile incelenmektedir. Öyle ki, geçerli bir faktör yapısı için KMO katsayısının 0,6'dan büyük ve Barlett Küresellik Testi ise anlamlı çıkması beklenmektedir (Büyüköztürk, 2011). Yapılan analizlerde, araştırmada kullanılan Yenilenme Deneyimi Ölçeğinin KMO katsayısı 0,806 olarak ölçülmüş, Bartlett Küresellik Testi ise anlamlı bulunmuştur $(p<, 000)$. Bulunan bu değerler, araştırmada kullanılan yenilenme deneyimi ölçeğinin açıklayıcı faktör analizi için uygun olduğunu göstermektedir (Büyüköztürk, 2011).

Araştırma kapsamında ayrıca, yenilenme deneyimi ölçeğini oluşturan her bir boyutun da iç tutarlılık değerleri analiz edilmiş ve analiz sonuçları Tablo 1'de gösterilmiştir. Tablo.1 incelendiğinde, ölçeği ilişkin her bir boyut iç tutarlılık değerlerinin 0.879 ile 0,783 arasında değiştiği görülmektedir. Bulunan bu değerlerin, boyutları oluşturan ifadelerin bir bütün olarak ölçümün güvenilirliğini kanıtladığı söylenebilir. 
Tablo 1. Yenilenme Deneyimi Ölçeğine İlişkin Faktör Analizi Sonuçları

\begin{tabular}{|c|c|c|c|}
\hline Boyutlar & Ölçek İfadeleri & $\begin{array}{c}\text { Faktö } \\
\text { r } \\
\text { Yükü }\end{array}$ & Varyans \\
\hline $\begin{array}{l}\text { İşten } \\
\text { Kopma }\end{array}$ & AVM'de bulunduğum esnada işim hakkında düşünmem. & 874 & 32,556 \\
\hline \multirow[t]{3}{*}{$\alpha=0,866$} & AVM'de bulunduğum esnada işimi unuturum. & ,865 & \\
\hline & AVM'de bulunduğum esnada işimle arama mesafe koyarım. & 800 & \\
\hline & AVM'de bulunduğum esnada işimden gelen taleplere aldırmam. & ,758 & \\
\hline $\begin{array}{l}\text { Karar } \\
\text { Verme }\end{array}$ & $\begin{array}{l}\text { AVM'de bulunduğum esnada kendi programıma kendim karar } \\
\text { veririm. }\end{array}$ & ,923 & 17,683 \\
\hline \multirow[t]{3}{*}{$\alpha=0,879$} & $\begin{array}{l}\text { AVM'de bulunduğum esnada zamanımı nasıl harcayacă̆ıma kendim } \\
\text { karar veririm. }\end{array}$ & ,910 & \\
\hline & $\begin{array}{l}\text { AVM'de bulunduğum esnada neyi nasıl yapmak istiyorsam o şekilde } \\
\text { yaparım. }\end{array}$ & ,895 & \\
\hline & $\begin{array}{l}\text { AVM'de bulunduğum esnada ne yapacă̆ıma kendim karar veriyor } \\
\text { gibi hissederim. }\end{array}$ & ,728 & \\
\hline Arayış & AVM'de bulunduğum esnada ufkumu genişletecek şeyler yaparım. & 810 & 13,024 \\
\hline \multirow[t]{3}{*}{$\alpha=0,783$} & AVM'de bulunduğum esnada entelektüel gelişme firsatı ararm. & ,762 & \\
\hline & AVM'de bulunduğum esnada beni zorlayan şeyleri yaparım. & ,719 & \\
\hline & AVM'de bulunduğum esnada yeni şeyler öğrenmeye çalışırım. & 698 & \\
\hline Rahatlama & $A V M^{\prime}$ de bulunduğum esnada rahatlatıcı şeyler yaparım. & - & 8,568 \\
\hline \multirow[t]{2}{*}{$\alpha=0,830$} & AVM'de bulunduğum esnada zamanımı gevşemeye ayırırım. & - & \\
\hline & AVM'de bulunduğum esnada kendime boş zaman ayırırım. & $\begin{array}{c}- \\
, 766\end{array}$ & \\
\hline
\end{tabular}

Toplam Varyans Açıklama Oranı: \%71,832 Cronbach's Alpha: 0,848 KMO: 0,806, Bartlett Küresellik Testi: P=,000

Tablo 2. Deneyimleme Kalitesi Ölçeğine İlişkin Faktör Analizi Sonuçları

\begin{tabular}{|c|c|c|c|}
\hline Boyutlar & Ölçek İfadeleri & $\begin{array}{l}\text { Faktör } \\
\text { Yükü }\end{array}$ & $\begin{array}{r}\text { Varyan } \\
\mathrm{s}\end{array}$ \\
\hline Ĕgitici & Ziyaret ettiğim yer hakkında yeni bilgiler edindim. & ,925 & 54,112 \\
\hline \multirow[t]{2}{*}{$\alpha=0,875$} & Ziyaret ettiğim yer hakkında birçok yeni şey öğrendim. & 899 & \\
\hline & Ziyaret ettiğim yer hakkında ufkum genişledi. &, 872 & \\
\hline $\begin{array}{l}\text { Ĕglendiric } \\
i\end{array}$ & Ziyaret ettiğim yerde olmaktan memnun oldum. &,- 950 & 13,24 \\
\hline \multirow[t]{2}{*}{$\alpha=0,900$} & Ziyaret ettiğim yeri gezmekten büyük keyif aldım. &,- 882 & \\
\hline & Ziyaretim boyunca eğlendim. &,- 869 & \\
\hline Kaçış & $\begin{array}{l}\text { Ziyaretim boyunca kendimi o kadar kaptırdım ki her şeyi } \\
\text { unuttum. }\end{array}$ & ,933 & 12,923 \\
\hline \multirow[t]{2}{*}{$\alpha=0,825$} & Ziyaretim boyunca her şeyden uzaklaştım. & 849 & \\
\hline & $\begin{array}{l}\text { Ziyaretim boyunca kendimi başka bir dünyadaymışım gibi } \\
\text { hissettim. }\end{array}$ & ,621 & \\
\hline
\end{tabular}

Toplam Varyans Açılama Oranı:\%80,275 Cronbach's Alpha: 0,893 KMO: 0,851

Bartlett Küresellik Testi: $P=, 000$ 
Araştırmada, deneyimleme kalitesi ölçeğine ilişkin KMO katsayısı 0,851; Bartlett Küresellik Testi ise anlamlı bulunmuştur $(\mathrm{p}<, 000)$. Deneyimleme kalitesi ölçeği boyutlarının iç tutarlılık değerlerinin 0,900 ile 0,825 arasında değişmesi, ölçeğin oldukça güvenilir olduğunu göstermektedir. Deneyimleme Kalitesi Ölçeğine ilişkin faktör analizi sonuçları ve güvenilirlik değerleri Tablo 2' de verilmiştir.

Tablo 3. Yaşam Memnuniyeti Ölçeğine İlişkin Faktör Analizi Sonuçları

\begin{tabular}{|c|c|c|c|}
\hline Boyutlar & Ölçek İfadeleri & Faktör Yükü & Varyans \\
\hline Hoşnutluk & Hayatımdan çok memnunum. & ,896 & 45,187 \\
\hline \multirow[t]{2}{*}{$\alpha=0,774$} & Hayatımı dolu dolu yaşıyorum. & 881 & \\
\hline & Hayatımda şu anda hiçbir şey eksik değildir. & ,713 & \\
\hline Yakınma & $\begin{array}{l}\text { Hayatımı bir bütün olarak analiz ettiğimde, arzularımı yerine } \\
\text { getirmediğimi hissediyorum* }\end{array}$ & 892 & 26,915 \\
\hline$\alpha=0,648$ & $\begin{array}{l}\text { Hayatımda yapmak istediğim her şeyi yapmadığım için } \\
\text { kendimi memnuniyetsiz hissediyorum* }\end{array}$ & 825 & \\
\hline
\end{tabular}

Son olarak, yaşam memnuniyeti ölçeğine ilişkin KMO katsayısı 0,630 olarak beklenen minimum değerin biraz üstünde ölçülmüş ve Bartlett Testi ise anlamlı bulunmuştur $(\mathrm{p}<, 000)$. Bu değerler, yaşam memnuniyeti ölçeğinin faktör analizi için uygun olduğunu göstermektedir (Büyüköztürk, 2011). Benzer şekilde, bu ölçeği oluşturan iki boyutun iç tutarlılık değeri sırasıyla 0,774 ve 0,648 olarak ölçülmüştür. Bulunan her iki değer ölçeğin güvenilir olduğunu göstermektedir. Yaşam memnuniyeti ölçeğine ilişkin faktör analizi sonuçları ve güvenilirlik değerleri Tablo 3 'de gösterilmiştir.

\section{ARAŞTIRMA BULGULARI}

Araştırmaya katılan katılımcıların demografik ve sosyo-ekonomik özellikleri, Tablo $4^{\prime}$ de gösterilmiştir. Tablo 4'e göre katılımcıların çoğunluğunun erkek olduğu (\%58), yaş özellikleri bakımından çoğunluğunun 30 yaş ve altında olduğu görülmektedir $(\% 53,4)$. Eğitim düzeyi bakımından, katılımcıların büyük bir çoğunluğunun lisans derecesine sahip olduğu dikkat çekmektedir $(\% 67,9)$. Son olarak katılımcların aylık gelirleri incelendiğinde $\% 40,1^{\prime}$ inin 3001 TL ve üzerinde aylık gelire sahip olduğu, \%33,8'inin ise 2001 TL ile 3000 TL arasında aylık gelire sahip olduğu görülmektedir.

AVM ziyaret sıklığının, katılımcıların yenilenme deneyimi, deneyimleme kalitesi ve yaşam memnuniyeti algıları üzerine etkisinin incelenmesi adına araştırmada, öncelikle dört değişken arasındaki korelasyon katsayıları ve anlamlılık değerleri incelenmiş ve bulunan değerler, Tablo $5^{\prime}$ te verilmiştir. 
Tablo 4. Katılımcıların Demografik ve Sosyo-Ekonomik Özellikleri

\begin{tabular}{|c|c|c|}
\hline Cinsiyet & $N$ & $\%$ \\
\hline Kadın & 148 & 42,0 \\
\hline Erkek & 204 & 58,0 \\
\hline Toplam & 352 & 100,0 \\
\hline Yaş & $N$ & $\%$ \\
\hline 30 Yaş ve Altı & 188 & 53,4 \\
\hline 31 - 50 Yaş Arası & 151 & 42,9 \\
\hline 51 Yaş ve Üzeri & 13 & 3,7 \\
\hline Toplam & 352 & 100,0 \\
\hline Ĕgitim Düzeyi & $N$ & $\%$ \\
\hline İlköğretim & 5 & 1,4 \\
\hline Ortaöğretim & 7 & 2,0 \\
\hline Lise & 54 & 15,3 \\
\hline Lisans & 239 & 67,9 \\
\hline Lisansüstü & 47 & 13,4 \\
\hline Toplam & 352 & 100,0 \\
\hline Aylik Gelir & $N$ & $\%$ \\
\hline 2000 TL ve Altr & 92 & 26,1 \\
\hline 2001 - 3000 TL Arası & 119 & 33,8 \\
\hline 3001 TL ve Üzeri & 141 & 40,1 \\
\hline Toplam & 352 & 100,0 \\
\hline
\end{tabular}

Tablo 5. Değişkenler Arası Korelasyon Analizi Sonuçları

\begin{tabular}{lcccc}
\hline & $\begin{array}{c}\text { AVM Ziyaret } \\
\text { Siklı̆̆ }\end{array}$ & $\begin{array}{l}\text { Yenilenme } \\
\text { Deneyimi }\end{array}$ & $\begin{array}{c}\text { Deneyimleme } \\
\text { Kalitesi }\end{array}$ & $\begin{array}{c}\text { Yaşam } \\
\text { Memnuniyeti }\end{array}$ \\
\hline $\begin{array}{l}\text { AVM Ziyaret } \\
\text { Siklı̆̆ı }\end{array}$ & - & & & \\
\hline $\begin{array}{l}\text { Yenilenme } \\
\text { Deneyimi }\end{array}$ &, $240^{*}$ & - & & \\
\hline $\begin{array}{l}\text { Deneyimleme } \\
\text { Kalitesi }\end{array}$ &, $314^{*}$ &, $634^{*}$ & - & - \\
\hline $\begin{array}{l}\text { Yaşam } \\
\text { Memnuniyeti }\end{array}$ &, 010 &, 027 &, 028 & \\
\hline${ }^{*}<<0,01$ & & & &
\end{tabular}

Korelasyon analizi sonuçlarına göre, AVM ziyaret sıklı̆̆ı ile yenilenme deneyimi ve deneyimleme kalitesi arasında bir ilişki vardır $(p=0,000)$. Ancak, AVM ziyaret sıklığı ile yaşam memnuniyeti arasında istatistiksel olarak anlamlı bir ilişki bulunamamıştır $(p=0,852)$. AVM ziyaret sıklığı ile, yenilenme deneyimi ve deneyimleme kalitesi arasında bulunan ilişkinin neden-sonuç ilişkisi olup olmadığının araştırılması adına regresyon analizinden yararlanılmıştır. Analiz öncesinde, basit doğrusal regresyon analizi öncülleri olan otokorelasyon (autocorrelation) sorunu ve normallik varsayımları araştırılmış ve otokorelasyon sorunu için verilen tüm regresyon modellerinde Durbin-Watson istatistiği değerlerinin kabul edilebilir değerler $(1,5 / 2,5)$ arasında olduğu görülmüştür (Hair vd., 2006). Sonrasında araştırma 
kapsamında verilen regresyon modelleri, Residual Plots yardımı ile incelenmiş ve elde edilen diyagramların, bağımlı değişkenlerde görülmesi beklenen desenlerle uyumlu olduğu ortaya çıkmıştır. Bu durum, araştırma kapsamında verilen regresyon modellerine ilişkin her bir veri setinin, normal dağılım şartını karşıladığını göstermektedir (Seltman, 2015). Akabinde, öncelikle AVM ziyaret sıklığı bağımsız değişken, yenilenme deneyimi ve deneyimleme kalitesi bağımlı değişken olarak ele alınarak ayrı ayrı analiz edilmiş ve sonuçlar Tablo 6 'da gösterilmiştir.

Tablo.6 AVM Ziyaret Sıklığı, Yenilenme Deneyimi ve Deneyimleme Kalitesi İlişkisi

\begin{tabular}{|c|c|c|c|}
\hline AVM Ziyaret Sıklığı ve Yenilenme Deneyimi & $\beta$ Katsayısı & $t$-değeri & $p$ \\
\hline (Sabit Değer) & 2,966 & 15,330 & $.000^{*}$ \\
\hline AVM Ziyaret Siklı̆̆l & 0,240 & 4,616 &, $000^{* *}$ \\
\hline$R 2=, 057 F=21,307 p=, 000$ & & \multicolumn{2}{|c|}{ Durbin-Watson Değeri $=1,84$} \\
\hline \multicolumn{4}{|l|}{${ }^{*} p<0,01$} \\
\hline AVM Ziyaret Siklı̆̆ı ve Deneyimleme Kalitesi & $\beta$ Katsayısı & $t$-değeri & $p$ \\
\hline (Sabit Değer) & 1,871 & 7,669 &, $000^{*}$ \\
\hline AVM Ziyaret Siklı̆ğ & 0,314 & 6,192 &, $000^{*}$ \\
\hline$R^{2}=, 099 F=38,346 p=, 000$ & & \multirow{2}{*}{\multicolumn{2}{|c|}{ Durbin-Watson Değeri $=1,742$}} \\
\hline${ }^{*} \mathrm{p}<0,01$ & & & \\
\hline
\end{tabular}

Tablo 6'da verilen AVM ziyaret sıklı̆̆ı ve yenilenme deneyimi regresyon analizi sonuçları incelendiğinde regresyon modeli anlamlı çıkmıştır $(F=21,307, p=, 000)$. Tabloda verilen $R^{2}$ değerine göre, AVM ziyaret sıklığı ile yenilenme deneyimi algısı arasında $\mathrm{R}^{2}=, 057$ düzeyinde bir ilişki bulunmuştur. Başka bir ifadeyle, AVM ziyaret sıklığı arttıkça, bireylerin bu ziyaretlerinden elde ettikleri yenilenme deneyimi algıları da yaklaşı $\% 6$ oranında artmaktadır. Bunun yanı sıra AVM ziyaret sıklığı ve deneyimleme kalitesi arasındaki ilişkiye yönelik regresyon analizi sonuçları incelendiğinde, benzer şekilde iki değişken arasında pozitif yönlü bir ilişkinin varlığı dikkat çekmektedir $\left(\mathrm{R}^{2}=, 099\right)$. Kısacası AVM ziyaret sıklığı, bireylerin deneyimleme kaliteleri üzerinde yaklaşık \%10 oranında etkilidir. Bireylerin boş zamanlarındaki AVM ziyaretleri arttıkça, deneyimleme kalitesi algıları da aynı yönde artış göstermektedir.

Tablo 7. Yenilenme Deneyimi ve Deneyimleme Kalitesi İlişkisi

\begin{tabular}{lccc}
\hline & $\beta$ Katsayıs1 & t-değeri & $\mathbf{p}$ \\
\hline & & & \\
(Sabit Değer) &, 196 &, 928 &, 354 \\
Yenilenme Deneyimi &, 634 & 15,35 &, $000^{*}$ \\
\hline$R^{2}=402$ F=235,617 $p=, 000$ Durbin-Watson Değeri $=1,838$ & & & \\
${ }^{*} p<0,01$ & & &
\end{tabular}

Yenilenme deneyimi ile deneyimleme kalitesi arasındaki neden sonuç ilişkisi Tablo 7'de, verilmiştir. Analiz sonucunda regresyon modelinin anlamlı olduğu görülmüştür ( $F=235,617$, $p=, 000$ ). Modele ilişkin $\mathrm{R}^{2}$ değeri incelendiğinde, yenilenme deneyimi alg1sı, deneyimleme kalitesi algısı üzerinde önemli derecede etkili olduğu görülmektedir $\left(R^{2}=402\right)$. Kısacası, 
bireylerin AVM ziyaretinden elde ettikleri deneyimleme kalitesi algıları ile yenilenme deneyimi algıları $\% 40$ oranında birbiriyle ilişkilidir.

Tablo.8 Hipotez Kabul veya Red Tablosu

\begin{tabular}{lcc}
\hline Araştırma Hipotezi & Kabul/Ret Durumu & Tablo Numarası \\
\hline H1 & Red & Tablo.5 \\
\hline H2 & Kabul & Tablo.6 \\
\hline H3 & Kabul & Tablo.6 \\
\hline$H 4$ & Kabul & Tablo.7 \\
\hline H5 & Red & Tablo.5 \\
\hline$H 6$ & Red & Tablo.5 \\
\hline
\end{tabular}

Tablo 8' de araştırma kapsamında test edilen hipotezlere ilişkin kabul veya red sonuçları ve her bir hipoteze ilişkin analiz tablo numaraları verilmiştir. Her bir araştırma hipotezine ilişkin yapılan analizler sonucunda $\mathrm{H} 2, \mathrm{H} 3$ ve $\mathrm{H} 4$ araştırma hipotezleri desteklenirken, H1, H5 ve H6 araştırma hipotezleri desteklenememiştir.

\section{SONUÇ}

Rekreasyon faaliyetleri gerek kapalı mekanlarda gerek açık alanlarda gerçekleştiğinde, bireylere hem zihinsel hem de fiziksel açıdan rahatlama olanağı sunmaktadır. Bireyler iş dışında ve evleri dışında boş zamanlarını çoğunlukla gezmek, dolaşmak, alışveriş yapmak, eğlenmek, yemek yeme, arkadaş çevreleriyle birlikte olmak gibi sosyal faaliyetlerle değerlendirmektedir. Bu faaliyetler için en uygun mekânların başında ise AVM'ler gelmektedir. Son yıllarda değişen hayat tarzları ile birlikte alışveriş, merkezleri toplumun büyük bir çoğunluğu için yeni rekreasyon merkezlerine dönüşmüştür. Bu nedenle AVM'lerin bir boş zaman değerlendirme ve rekreasyon faaliyeti olarak ortaya çıkmasıyla, insanların bu kapalı mekanlarda boş zamanlarının değerlendirmesinin, etkilerinin bilinmesini gerekli kılmıştır. Bireylerin boş zaman aktivitesi olarak AVM ziyaret sıklığı ile yaşam memnuniyeti, yenilenme deneyimleri ve deneyimleme kalitesi arasındaki ilişkinin tespit edilmesine yönelik gerçekleştirilen bu çalışma alan yazında bu üç değişken arasındaki ilişkinin tespiti üzerine yapılan tek çalışma olması açısından önem taşımaktadır.

Araştırma kapsamında geliştirilen hipotezler doğrultusunda araştırma sonucunda AVM ziyaret sıklı̆̆ bunun yanı sıra yenilenme deneyiminin de deneyimleme kalitesini olumlu yönde etkilediği sonucuna ulaşılmıştır.

Çalışmada AVM ziyaret sıklığının yenilenme deneyimini olumlu yönde etkileyeceği üzerine geliştirilen hipotez çalışma kapsamında kabul edilmiştir. Daha önceki çalışmalarda bu iki değişken arasındaki ilişkiyi araştıran bir çalışmaya rastlanmamaktadır. Fakat, bilindiği gibi AVM'ler, günümüzde insanların boş zamanlarında rahatlamak, eğlenceli vakit geçirmek, yenilenmek ve yeni deneyimler yaşamak için ziyaret ettiği modern mekanlar haline gelmiştir. İnsanlar boş vakitlerinde alışveriş yapmak, eğlenmek, yemek yemek, boş vakit geçirmek vb. nedenlerle AVM'leri ziyaret etmektedir. Bu tarz aktivitelerin boş zaman ve rekreasyon faaliyetlerinin temel varsayımı olan yenilenme ihtiyacını karşıladığı düşünüldüğünde, AVM 
ziyaretlerinin sıklığının yenilenme deneyimini etkilemesi literatürde boş zaman ve rekreasyon faaliyetlerine yönelik temel varsayımlarıyla örtüşmektedir.

AVM ziyaret sıklığı bireylerin deneyimleme kalitesini olumlu yönde etkilemektedir hipotezi de çalışma kapsamında yapılan analiz bulguları sonucunda doğrulanmıştır. Bireylerin boş zamanlarındaki AVM ziyaretleri arttıkça, deneyimleme kalitesi algıları da aynı yönde artış gösterdiği söylenebilir. Daha önceki çalışmalarda bu iki değişken arasındaki ilişkiyi araştıran bir çalışmaya rastlanmadığı için literatürden destekleyici örnekler verilememektedir. Ancak AVM'lerde deneyimleme imkânı sunan aktivitelerin çeşitlilik göstermesi bireylerin deneyimleme kalitesi algısını arttırmaktadır. AVM'ler de çeşitli etkinliklere katılan bireyler hem deneyim yaşayacak hem de iş stresinden uzaklaşıp kaçış duygusunu hissedeceklerdir.

Çalışma kapsamında geliştirilen deneyimleme kalitesinin yenilenme deneyimi üzerindeki etkisini inceleyen hipotez kabul edilmiştir. Yine alan yazın incelendiğinde bu ilişkiyi inceleyen öncül bir çalışma bulunamamıştır. Bununla birlikte, Altunel ve Akova (2016), yenilenme deneyimini etkileyen faktörlerin belirlenmesi amacıyla tatile çıkan insanlar üzerine yaptıkları çalışmada, deneyimleme kalitesinin yenilenme deneyimini etkilediğini bulgulamışlardır. Tatile çıkmanın uzun süreli bir boş zaman değerlendirme ve rekreasyon faaliyeti olduğu düşünüldüğünde, kısa süreli bir boş zaman değerlendirme ve rekreasyon faaliyeti olan AVM ziyaretini konu alan bu çalışmayla benzer sonuçlar elde edildiği görülmektedir. Bireylerin sunulan hizmeti tükettikleri an yaşadıkları deneyim kalitesi yenilenme deneyimini etkilemesi ve bu yenilenme deneyiminin de bireyin nihai memnuniyetine katkı sağlayacağı (Altunel vd., 2016) fikrinde yola çıkarak AVM'ler de sunulan çeşitli aktivite imkanları vasıtasıyla deneyim hissini gerçekleştiren bir birey stres unsurları yok ederek mikro veya makro seviyede gerçekleşen bir iyi olma hali içerisine olacaktır.

Alan yazında boş zamanın yaşam memnuniyetine olan etkisini üzerinde olumlu yönde etki sağladığına yönelik birçok çalışmanın (Gilbert ve Abdullah, 2004; Neal vd., 2007; Sirgy vd., 2011, Coyle, vd., 1994; London, vd., 1977; Agyar, 2013; Lapa, 2013; Neal, vd., 1999; Neal vd., 2007; Lin vd., 2013) mevcut olmasına rağmen bu çalışmada rekreatif aktivite olarak AVM ziyaret sıklığının yaşam memnuniyeti üzerinde herhangi bir etkisinin olmadığını göstermiştir. AVM ziyaret sıklığının yaşam memnuniyetini etkilememesi önemli bir bulgu olarak ortaya çıkmıştır. İş ve boş zamanları değerlendirme gibi pek çok farklı yaşam alanlarından elde edilen doyumun tamamından oluşan bir duygusal tepki olarak nitelendirilen (Diener, 1984) yaşam memnuniyeti kavramı başarmak istenen ile elde edilen çıktıların kıyaslanması sonucunda sübjektif bir yargı şeklinde oluşmaktadır (Pavot ve Diener, 1993). Bu nedenle AVM ziyaretlerinin yaşam memnuniyeti üzerine etkisinin daha kapsamlı bir şekilde araştırılması gerekmektedir.

\section{KAYNAKÇA}

Aktaş, G. G. (2011). Çağdaş Alışveriş Merkezlerinde Rekreasyonel İç Mekân Organizasyonu Önerileri, Sanat \& Tasarm Dergisi, 1: 1-14.

Altunel, M. C. ve Akova, O. (2016). Yenilenme Deneyimini Etkileyen Faktörlerin Belirlenmesi: Tatil Esnasında İş ve Tatille İlgili Akıllı Telefon Kullanımı, İşle Tatilin Birbirine Karışması ve Deneyimleme Kalitesi. Afyon Kocatepe Üniversitesi Sosyal Bilimler Dergisi, 18(2): 341-360.

Altınay, M. ve Bilginöz, S. (2015). Alışveriş Merkezlerinin Tercih Edilme Nedenleri ve Rekreasyonla İlişkisi. Journal of Recreation and Tourism Research, 2(3), 37-47. 
Argan, M. (2007). Eğlence Pazarlama. Ankara: Detay Yayıncılık.

Akgündüz, Y. (2013). Konaklama İşletmelerinde İş Doyumu, Yaşam Doyumu ve Öz Yeterlilik Arasındaki İlişkinin Analizi. CBÜ Sosyal Bilimler Dergisi, 11(1): 180-204.

Agyar, E. (2013). Life Satisfaction, Perceived Freedom in Leisure and Self-Esteem: The Case of Physical Education and Sport Students. Procedia-Social and Behavioral Sciences. 93, 2186-2193.

Büyüköztürk, Ş. (2011). Sosyal Bilimler İçin Veri Analizi El Kitabı. Ankara: Pegem.

Bayer, M.Z. (1992). Turizm Giriş, İstanbul.

Bellenger, D. N. and Korgaonkar, P.K. (1980). Profiling the Recreational Shopper. Journal of Retailing, 56(3), 77-92.

Bucher, C. A. and Bucher, R. D. (1974). Recreation for today's Society. New Jersey: Frentice-Hall.

Bozkurt, S. G. ve Ulus, A. (2014). Rekreasyonel Amaçlı Kullanılan Alışveriş Merkezlerinde İç Mekân Bitkilerinin Organizasyonu ve Kullanım Parametrelerinin İstanbul (Avrupa Yakası) Örneğinde İncelenmesi. Journal of the Faculty of Forestry Istanbul University, 64(2): 24-40.

Berry, L.L., Carbone, L.P., and Haeckel, S.H. (2002). Managing the total customer experience. MIT Sloan Management Review, 43(3), 85-89.

Carbone, L.P. and Haeckel, S.H. (1994). Engineering customer experiences. Marketing Management, 3(3), 8-19.

Chang, T. Y. and Horng, S. C. (2010). Conceptualizing and Measuring Experience Quality: The Customer's Perspective, Service Industries Journal, 30(14): 2401-2419.

Chakrapani, C. (2004). Tatistics In Market Research. London: Arnold Publisher.

Chen, C. C., Petrick, J. F. and Shahvall, M. (2014). Tourism Experiences a Stress Reliever: Examining the Effects of Tourism Recovery Experiences on Life Satisfaction. Journal of Travel Research, 55(2): 1-11.

Cronbach, L. J. (1990). Essentials of Psychological Testing. New York: Harper \& Row.

Csikszentmihalyi, M., and LeFevre, J. (1989). Optimal Experience in Work and Leisure. Journal of Personality and Social Psychology, 56(5), 815-822.

Clawson, M. and Kenetsch, J. L. (1971). Economic of Outdoor Recreation. The John Hopkins Press. Baltimore and London.

Chen, C. C., Huang, W. J., and Petrick, J. F. (2016). Holiday recovery experiences, tourism satisfaction and life satisfaction-Is there a relationship? Tourism Management, 53, 140-147.

Coyle, C. P., S. Lesnik-Emas and W. B. Kinney (1994). Predicting Life Satisfaction among Adults with Spinal Cord Injuries. Rehabilitation Psychology, 39 (2): 95-112.

Derks, D. and Bakker, A. (2014). Smartphone Use, Work-Home Interference, and Burnout: A Diary Study on the Role of Recovery. Applied Psychology: An International Review, 63(3): 411-440.

Dikmen, A. A. (1995). İş Doyumu ve Yaşam Doyumu İlişkisi. Ankara Üniversitesi SBF Dergisi, 50(3): 115-140.

Derks, D. and Bakker, A. (2014). Smartphone Use, Work-Home Interference, and Burnout: A Diary Study on the Role of Recovery. Applied Psychology: An International Review, 63(3), 411-440.

Erkip, F. (2003). The Shopping Mall as an Emergent Public Space in Turkey, Environment and Planning A, 35: 1073-1093. 
Eastlick, M. A., Lotz, S. and Shim, S. (1998). Retail-tainment: Factors Impacting Crossshopping in Regional Malls. Journal of Shopping Center Research (JSCR), 5(1), 7-31.

Edginton, C. R. and Ford, M. P. (1985). Leadership in Recreation and Leisure Service Organizations. J. Wiley Sons., 5.

Eren, Hande. (2009). İstanbul İlindeki İş Yerlerinde Yöneticilerin Rekreasyon Kavramı ve Uygulamalarına Bakış Açlarının Değerlendirilmesi. Yüksek Lisans Tezi, Marmara Üniversitesi, İstanbul.

Fitcher, J. (2011). Sosyoloji Nedir? (Çev: Nilgün Çelebi), Ankara: Anı Yayıncılık.

Fick, G. and Ritchie, J. (1991). Measuring Service Quality in the Travel and Tourism Industry, Journal of Travel Research, 30 (2): 2-9.

Gilbert, D. and J. Abdullah (2004). Holiday Taking and the Sense of Well-Being, Annals of Tourism Research, 31 (1): 103-21.

İsmailoğlu, H. (2003). Bilimsel Araştırma Yöntemleri. İstanbul: Beta Yayınları.

Kang, M. and Gretzel, U. (2012). Effects of Podcast Tours on Tourist Experiences in a National Park. Tourism Management, 440-455.

Kartal, M. (2015). Gaziantep Şehrinde Rekreasyonel Faaliyetlerin Dağılışı, Yüksek Lisans Tezi, İstanbul Üniversitesi, Sosyal Bilimler Enstitüsü, İstanbul.

Kaya, İ. (2015). Alışveriş Merkezi Tüketicilerine Yönelik Rekreatif Alışveriş Ölçeği'nin Geliştirilmesi: İstanbul Örneği, Seyahat ve Otel İsletmeciliği Dergisi, 11(1): 58-68.

Kılıç, M. ve Şener, G. (2013). Üniversite Öğrencilerinin Rekreasyon Etkinliklerine Katılımlarındaki Sosyolojik Etkenler ve Yapısal Kısıtlamalar. Yükseköğretim ve Bilim Dergisi, 3(3): 220-227.

Kanbur, E. ve Özdemir, B. (2017). Yaşam Memnuniyeti ve Öncülleri: Karadeniz Bölgesi Incelemesi. Al-Farabi Uluslararası Sosyal Bilimler Dergisi, 1(1), 147-157.

Karaküçük, S. (2001). Rekreasyon boş zamanları değerlendirme (Dördüncü baskı). Ankara: Gazi Kitabevi, 21-30.

Kraus, R. G. (1985). Recreation Program Planning Today. Scott Foresman and Company, London.

Lavallee, L. F., Hatch, P. M., Michalos, A. C. and Mckinley, T. (2007). Development Of The Contentment With Life Assessment Scale (CLAS) Using Daily Life Experiences To Verify Levels Of Self-Reported Life Satisfaction. Social Indicators Research, 201-244.

London, M., R. Crandall and G. W. Seals (1977). The contribution of job and leisure- satisfaction to quality of life, Journal of Applied Psychology, 62 (3): 328-34.

Lapa, T.Y. (2013). Life satisfaction, leisure satisfaction and perceived freedom of park recreation participants. Procedia-Social and Behavioral Sciences, 93, 1985- 1993.

Lepp, A. (2018). Correlating leisure and happiness: the relationship between the leisure experience battery and the Satisfaction with Life Scale. Annals of Leisure Research, 21(2), 246252.

Lin, J. H., Wong, J. Y. and Ho, C. H. (2013). Promoting Frontline Employees' Quality of Life: Leisure Benefit Systems and Work-To-Leisure Conflicts. Tourism Management, 36, 178-187.

Uysal, M. and Sirgy, M. J. (2019). Quality-of-life indicators as performance measures. Annals of Tourism Research, 76, 291-300. 
Müderrisoğlu, H. ve Uzun, S. (2004). Abant İzzet Baysal Üniversitesi Orman Fakültesi Öğrencilerinin Rekreasyonel Eğilimleri, Süleyman Demirel Üniversitesi Orman Fakültesi Dergisi, A (2): 108-121.

Mirzeoğlu, N. (2003). Spor Bilimlerine Giriş. Bă̆ırgan Kitapevi,İstanbul.

Maddison, D. and Rehdanz, K. (2011). The Impact of Climate on Life Satisfaction. Ecological Economics, 70: 2437-2445.

Ngoo, T. Y., Tey, P. N. and Tan, C. E. (2015). Determinants of Life Satisfaction in Asia, Soc Indic Res., 124: 141-156.

Neal, J. D., M. Uysal and M. J. Sirgy (2007). The effect of tourism services on travelers' Quality of Life. Journal of Travel Research, 46: 154-63.

Neal, J. D., M. J. Sirgy and M. Uysal (1999). The Role of Satisfaction with Leisure Travel/Tourism Services and Experiences in Satisfaction with Leisure Life and Overall Life. Journal of Business Research, 44 (3): 153-64.

Odabaşı, Y. (1999). Tüketim Kültürü, Birinci Baskı, İstanbul: Sistem Yayınc1lık.

Ozankaya, Ö. (1980). Toplum bilim Terimleri Sözlü̆̆̈̈̈ (II. Baskı). TDK, Ankara.

Proto, E. and Rustichini, A. (2015). Life Satisfaction, Income and Personality. Journal of Economic Psychology, 48: 17-32.

Pine, B.J., and Gilmore, J.H. (1998). Welcome to the experience economy. Harvard Business Review (July-August), 97-105.

Sayar Y. ve Süer, D. (2001). Değişen Tüketim Örüntüleri - Alışveriş Mekanları, Arrademento Mimarlik, 11:105

Sonnentag, S. and Fritz, C. (2007). The Recovery Experience Questionnare: Development and Validation of a Measure for Assessing Recuperation and Unwinding from Work, Journal of Occupational Health Psychology, 12: 204-221.

Sağcan, M. (1986). Rekreasyon ve Turizm. İzmir.

Sonnentag, S. and Fritz, C. (2007). The Recovery Experience Questionnare: Development and Validation of a Measure for Assessing Recuperation and Unwinding from Work, Journal of Occupational Health Psychology, 12, 204-221.

Sirgy, M. J., Kruger, P. S., Lee, D. J. and Grace, B. Y. (2011). How Does A Travel Trip Affect Tourists' Life Satisfaction?. Journal of Travel Research, 50(3), 261-275.

Şentürk, Ü. (2012). Tüketim Toplumu Bağlamında Boş Zamanların Kurumsallaştırdığı Bir Mekân: Alı̧̧veriş Merkezleri (AVM). Pamukkale Üniversitesi Sosyal Bilimler Enstitüsü Dergisi, 13: 63-77.

Tezcan, M. (1982). Sosyolojik Açıdan Boş Zamanların Değerlendirilmesi. Ankara Üniversitesi Eğitim Fakültesi Yayınları, No: 116, Ankara.

Tunçel, E. F. (1999). Ortaöğretim Kurumlarında Görev Yapan Öğretmenlerin Boş Zamanlarını Değerlendirme Alışkanlıklarında Sporun Yeri, Yayınlanmamış Yüksek Lisans Tezi, Ege Üniversitesi, Sosyal Bilimler Enstitüsü, İzmir.

Toker, F., Çankaya, C. ve Doğan, M. (2003). Uludağ Üniversitesinde Öğrenim Gören Yabancı Uyruklu Öğrencilerin Boş Zaman Etkinliklerine Katılımlarının Araştırılması. Uludağ Üniversitesi Eğitim Fakültesi Dergisi, 17(1). 
Türkoğlu, H., Bölen, F., Korca, P. ve Marans, R. (2008). İstanbul'da yaşam kalitesinin ölçülmesi. itüdergisi/mimarlk, planlama, tasarım, 7(2), 103-113.

Türk Dil Kurumu (1932). Rekreasyon. Güncel Türkçe Sözlük. Erişim: http://www.tdk.gov.tr/index.php?option=com_gts\&arama=gts\&guid=TDK.GTS.5af4659ebe8602. 12324558. (Erişim tarihi: 10.01.2018).

Wagner, C. G. (2006). The Well-Being of Nations. Futurist, 40: 12 